How to cite this article:

Tan, K. E., Ng., M. L. Y., Abdullah, A., Ahmad, N., Phairot, E., Jawas, U., \& Liskinasih, A. (2020). Indonesian, Malaysian and Thai secondary school students' willingness to communicate in English. Malaysian Journal of Learning \& Instruction, 17(1), 1-24. https://doi.org/10.32890/mjli2020.17.1.1

\title{
INDONESIAN, MALAYSIAN AND THAI SECONDARY SCHOOL STUDENTS' WILLINGNESS TO COMMUNICATE IN ENGLISH
}

\author{
${ }^{1}$ Kok-Eng Tan, ${ }^{2}$ Melissa Ng Lee Yen Abdullah, ${ }^{3}$ Amelia \\ Ábdullah, ${ }^{4}$ Norlida Ahmad, \\ ${ }^{5}$ Ekkapon Phairot, ${ }^{6}$ Umiati Jawas \& ${ }^{7}$ Ayu Liskinasih \\ ${ }^{1-4}$ School of Educational Studies, Universiti Sains Malaysia, \\ Malaysia \\ ${ }^{5}$ Songkhla Rajabhat University, Thailand \\ ${ }^{6-7}$ Department of English Language and Literature \\ Universitas Kanjuruhan Malang, Indonesia

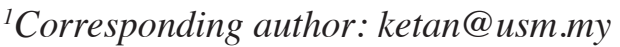

Received: 6/9/2018 Revised: 14/7/2019 Accepted: 10/11/2019 Published: 31/1/2020

\section{ABSTRACT}

Purpose - This quantitative study explored willingness to communicate (WTC) across two settings, ESL in Malaysia, and EFL in Indonesia and Thailand. Participants' WTC levels were measured and communicative situations in which participants were almost always willing and almost never willing to communicate in English were identified.

Method - Convenience sampling was used to select the three countries, four secondary schools and 42 intact classes from Years 7 to 10 . Two schools were in Malaysia, while one school each was in Indonesia and Thailand. A total of 1038 participants, consisting of 291 Malaysians, 325 Indonesians and 422 Thais took part in the study. The instrument used was an adapted questionnaire measuring WTC inside and outside the English classroom. 
Findings - The major findings were: 1) Situations in which students were almost never willing to communicate in English were mainly found outside the classroom; 2) Students were almost always willing to communicate in English in brief, predictable situations requiring the use of set phrases; 3) ESL students had a higher level of WTC than EFL students; and 4) WTC inside the classroom was significantly higher than WTC outside the classroom.

Significance - The findings have implications for ESL/EFL classroom instruction. English teachers remain the main interlocutors in increasing WTC in the classroom. They also need to bridge the gap between the classroom and the outside world by preparing students for real social situations. This is consistent with the situation-specific aspect of WTC in the heuristic model proposed by MacIntyre, Clément, Dörnyei, \& Noels (1998).

Keywords: ESL, EFL, interlocutors, secondary school, willingness to communicate.

\section{INTRODUCTION}

English teachers, especially in an ESL or EFL context, aim to produce students who can communicate competently in authentic situations. Getting one's message across effectively is an overall objective in speaking classes. The achievement of this objective is affected by students' willingness to communicate (WTC), which is defined as their free choice to initiate communication when the occasion arises (McCroskey \& Baer, 1985). To expand this definition further, in the teaching and learning of English, WTC is the intention to not only initiate interaction but also respond to an utterance or cue to speak in English. This intention is expressed by Cao and Philp (2006) as "to seek out communication opportunities" (p. 481). Readiness to avail oneself to the instances of language use in or outside the language classroom means to be willing to communicate. Many researchers believe that WTC opens up opportunities for the non-native speaker to use, explore and learn the language. As stated by Kang (2005), "L2 learners with a high WTC are more likely to use L2 in authentic communication and facilitate language learning" (p. 278). It follows that if students avoid using the target language, it is unlikely that they will succeed in learning it (Compton, 2002). 
The present study is an attempt to explore WTC among three groups of adolescent English learners, namely Indonesian, Malaysian and Thai students. All the learners live in an Asian non-native Englishspeaking environment. However, English is a second language in Malaysia (Ministry of Education of Malaysia, 2013) but a foreign language in Indonesia (Alwasilah, 2013) and Thailand (Ministry of Education Thailand, 2008). As such, learners' WTC in environments that differ in terms of opportunity for authentic communication in English is worthy of investigation. Would opportunities to speak and communicative situations affect learners' WTC? Furthermore, as the literature on WTC suggests that language learning is facilitated by greater WTC, findings would inform classroom instruction.

This quantitative study used descriptive and inferential statistics to answer the following research questions:

1. What are the top five situations in which students are (a) almost always willing to communicate in English, and b) almost never willing to communicate in English?

2. Is there a significant difference among Indonesian, Malaysian and Thai students in (a) overall WTC, (b) WTC in the classroom, and (c) WTC outside the classroom?

3. Is there a significant difference between WTC in the classroom and WTC outside the classroom among (a) Indonesian students, (b) Malaysian students, and (c) Thai students?

\section{Theoretical Perspectives}

WTC is a "personality-based predisposition" construct first proposed by McCroskey and Baer (1985, p. 4). Their WTC-Trait Form scale was found to be valid in measuring an individual's general predisposition towards WTC across four communication contexts and three types of receivers, with strong correlations found among all seven of its subscores. In explaining WTC as the intention (or inclination) to initiate communication out of one's free will, McCroskey and Baer's (1985) work has led to research on other factors that can affect intention. These have included competency, intergroup relationships and motivation variables found in the more complex non-native language context. Thus, from a relatively static and stable trait attached to the learner's personality, WTC has also become regarded as a dynamic state. State WTC is situational and changes with other variables. 
To explain the phenomenon of L2 WTC, MacIntyre, Clément, Dörnyei and Noels' (1998) heuristic model has been found useful. In the non-native context, this model helps to account for why a learner is found using or not using the target language. The pyramid-shaped model has six interrelated layers, moving down from Layer I at the apex to Layer VI at the base. The layers are: I - Communication Behaviour, II - Behavioural Intention, III - Situated Antecedents, IV - Motivational Propensities, V - Affective-Cognitive Context and VI - Social and Individual Context. In this pyramid, the last three (Layers IV, V, VI) broader bases of "stable, enduring" influences taper upwards to the top three (Layers, I, II, III) "situation-specific" influences on WTC (Lahuerta, 2014, p. 40). WTC (Layer II) is a behavioural intention that ends in the act of communication (Layer I). As given in the model, the factors leading to WTC come from psychological, social, affective and cognitive perspectives. The stand of the current study leans towards situational or state WTC with a focus on Situated Antecedents in Layer III which consist of Desire to communicate with a specific person and State communicative self-confidence (MacIntyre et al., 1998). These two components are strongly linked to what is outside the language learner; they are not fixed but change with the situation. The communication situation which is constituted by the location of the interaction (e.g., library, classroom, airport), the interlocutors (e.g., peer, teacher, stranger) and purpose of the communication (e.g., formal or informal) has a significant influence on the learner's WTC. Such views have been shared and explained by Cameron $(2013,2015)$, Kang (2005), MacIntyre, Baker, Clément and Conrod (2001) and PiechurskaKuciel (2014).

\section{Review of Related Studies}

In line with its multiple diverse influences, WTC has been linked to communicative apprehension or anxiety and (self-perceived) communicative competence (e.g., Lahuerta, 2014; MacIntyre, 1994; MacIntyre \& Charos, 1996; Piechurska-Kuciel, 2014), motivation (e.g., Baker \& MacIntyre, 2000; Matsuoka, 2004), attitudes towards English as an international language (e.g., Yashima, Zenuk-Nishide, \& Shimizu, 2004) and sociocultural factors (e.g., Matsuoka, Matsumoto, Poole, \& Matsuoka, 2014; Wen \& Clément, 2003).

Investigating actual English proficiency instead of perceived competence as a factor, Matsuoka (2004) found no significant 
correlation between WTC and English proficiency in a Japanese EFL college context. The proficiency of the 32 nursing students in this study was measured using the online Computerized Assessment System for English Communication, CASEC. In a study on 297 information science majors in a university in Osaka, Yashima (2002) used structural equation modelling to study the network of relationships involving WTC, motivation, self-confidence, proficiency and other factors. Proficiency scores were taken from the participants' TOEFL results. Yashima reported no direct influence of English proficiency on WTC. However, more recently Tan and Phairot (2018) found significant differences in WTC levels between low, moderate and high proficiency $12^{\text {th }}$ grade students in South Thailand. The English proficiency of the 375 students in this study was measured by the Ordinary National Educational Test or O-NET, administered by the National Institute of Educational Testing Service, NIETS.

Studies on trait and state WTC, either in the L1 or L2 context, have been attempted with varying results. For example, MacIntyre et al. (2001) supported the trait-like feature of WTC in an L2, while MacIntyre, Babin, and Clément (1999) confirmed that trait and state WTC complemented each other in an L1. Cao and Philp's (2006) study using quantitative and qualitative approaches differentiated between trait and state WTC and showed both their contributions to WTC behaviour. Their participants were eight adult L2 learners in a private language school in New Zealand. Kang (2005) reported a qualitative study on four Korean male students studying at an English Language Institute on a campus in the USA. The findings showed how situational WTC in the L2 changes along with the unfolding of a communication situation that is unpredictable due to the interplay of variables such as topic, interlocutors and conversational context. While situational WTC changes moment to moment during an interaction, trait-like WTC is already formed prior to the communication situation. Both interact to produce "the ultimate WTC" at the point of communication (p. 290).

One strand of research on the situational trait of WTC focuses on the learning context and the environment in which authentic communication happens. Thesecontextual factors concern the situated antecedents in Layer III of MacIntyre et al.'s (1998) model. Situated antecedents are made up of two components. The first component is desire to communicate with a specific person. This has to do with 
how affiliated a learner is towards the person s/he is speaking to. The stronger the affiliation (e.g., the learner shares similarity with and frequently encounters the interlocutor), the higher the level of WTC. The second related component is state communicative self-confidence, which is explained as perceived competence and lack of anxiety. This is clearly supported by Piechurska-Kuciel's (2014) view of WTC in L2 as "psychological readiness to engage in interaction" (p. 315), where L2 perceived competence is a better predictor of WTC than language anxiety. Perceived communication competence and communication apprehension are two situated antecedents close to WTC. They change according to the situation in which the learner is required to address the interlocutor, who may be the teacher, a stranger or a classmate. To be willing to engage with someone, the topic, interlocutors and conversational context are essential contextual considerations (Kang, 2005).

Whether inside or outside the classroom, the learner's willingness is preceded by a desire and the self-confidence to communicate with a specific person. MacIntyre et al. (2001) conducted a study in French as an L2 among 79 grade nine students in Canada. They found a significant correlation between WTC inside and outside the classroom. Furthermore, willingness to speak and write in French was significantly higher inside than outside the classroom. Cameron (2013) reported an exploratory study among permanent Iranian migrants in a New Zealand university and identified six factors affecting WTC, namely, self-perceived communicative competence, personality, anxiety, motivation and importance of English, and learning context. Pursuing the learning context using a qualitative approach, Cameron (2015) found that situational factors (i.e., learning English in Iran as contrasted with learning English in New Zealand) were more dominant than the personality factor in explaining WTC. Similarly, the importance of the learning context was supported by Cao (2011), Peng (2012) and Zhong (2013).

Continuing the line of investigation on situational factors and interlocutors, the present study was undertaken to examine the levels of WTC in and outside the English classroom among secondary school students in three non-native English speaking countries. It used the heuristic model, in particular the situated antecedents in Layer III, to make sense of the empirical data obtained. It focused on WTC in and outside classroom contexts as it relates to the desire 
to communicate with a specific recipient, i.e., a friend, teacher or stranger.

\section{METHODOLOGY}

A survey was conducted in four secondary schools (coded W, X, Y, $\mathrm{Z}$ ) among students in grades 7 to 10 . Convenience sampling was used to select the three countries for the study. An international teaching practicum in a Malaysian university partnering two schools in Malaysia and one in Indonesia gave the researchers the opportunity to collect data with the help of the teacher trainees. The classes were the teacher trainees' own classes or classes that were available at the time of data collection. As for Thailand, the participating school was conveniently sampled by a Thai doctoral student who was one of the researchers in this study. The classes in this school were selected by the school administrator to give a fair representation of gender, academic performance and English proficiency. The breakdown of participants is shown in Table 1.

Table 1

Participating Schools, Grades and Classes

\begin{tabular}{cccccc}
\hline \multirow{2}{*}{ School } & \multicolumn{5}{c}{ Number of classes } \\
\cline { 2 - 6 } & $\begin{array}{c}\text { Grade } 7 \\
(13 \text { yrs })\end{array}$ & $\begin{array}{c}\text { Grade } 8 \\
(14 \text { yrs })\end{array}$ & $\begin{array}{c}\text { Grade } 9 \\
(15 \text { yrs })\end{array}$ & $\begin{array}{c}\text { Grade 10 } \\
(16 \text { yrs })\end{array}$ & $\begin{array}{c}\text { Enrolment } \\
\text { of students }\end{array}$ \\
\hline W (Indonesia) & 4 & 4 & 4 & - & 325 \\
X (Malaysia) & 3 & 1 & - & 2 & 181 \\
Y (Malaysia) & 4 & 4 & - & 4 & 110 \\
Z (Thailand) & - & 4 & 4 & 4 & 422 \\
Total classes & 11 & 13 & 8 & 10 & 42 classes \\
\hline
\end{tabular}

\section{Indonesian EFL School Setting: School W}

School W was a public junior high school (Sekolah Menengah Pertama in Indonesian) located in an urban area in Malang, the second largest city in East Java, Indonesia. At the time of the study, the students, who were from a Javanese background, totalled 929. 
English was taught by seven English teachers using $60 \%$ Indonesian and $40 \%$ English. The main source of reference for each grade was an E-textbook provided by the Indonesian government. These prescribed textbooks had substituted English cultural values with Indonesian ones to reduce the perceived negative impact of western liberal values associated with the knowledge of English (Lauder, 2008). The teachers also created their own teaching materials based on the themes and focus of the curriculum. English classes emphasised grammar drills, presentation of tasks for practice in speaking, and multiple-choice questions for reading comprehension. Writing was only introduced in small doses at grade 8. Some students attended private tuition classes. Outside the English classroom, English was not spoken in the school.

\section{Malaysian ESL School Setting: School X}

School X was a public high school in the small town of Penaga, located on the west coast of Peninsular Malaysia, facing Penang island. The majority of the residents were fishermen or farmers. The students, who came from the surrounding villages, were Malays. At the time of the study, the school had a student enrolment of 1083. The six English teachers were also Malays and they used the Malay language (60\%) and English (40\%) in the English classroom. The English syllabus focused on the four language skills, grammar and literature. Textbooks prescribed by the Ministry of Education taught general proficiency and literature (poems, short stories and dramas). The teachers supplemented the textbooks with their own materials sourced from the Internet, practice books or other reference materials. English lessons had a constant reference to exam requirements. English was hardly heard outside the English classroom. The students did not have any extra English classes outside the school.

\section{Malaysian ESL School Setting: School Y}

Being a government school, School $\mathrm{Y}$ was similar to School $\mathrm{X}$ in terms of the English syllabus, prescribed textbooks and emphasis on exams. However, this was an urban all girls secondary school on Penang island. The 387 students were made up of Malays, Chinese and Indians. The four English teachers conducted English classes entirely in English. Exercises from various sources were used to support teaching and prepare students for exams. The students 
did not attend any English tuition classes outside the school. For communication between the different ethnic groups, the Malay language was predominantly used.

\section{Thai EFL School Setting: School Z}

School $\mathrm{Z}$ was a public high school teaching lower and upper secondary levels in the province of Trang, southern Thailand. The students were all Thais from different socio-economic backgrounds. School Z came under the Ministry of Education. English was taught as a core compulsory foreign language besides French and Chinese. Updated online statistics by The Educational Management Information System (2017) revealed that at the time of the study, there were 1,810 students enrolled in grades 7-12, and 136 teachers and staff in the school. There were 17 foreign language teachers, comprising 13 Thai and 4 foreign teachers. One Thai teacher taught French while another taught Chinese. English was taught by Thai teachers and two Filipino teachers. In English classes, it was common to observe the use of Thai language (80\%) and English $(20 \%)$. Outside the classroom, English was not used in teacherstudent interactions. Code-switching between Thai and English was sometimes used by students in their close circle of friends. The students from richer families went for extra English classes in tuition centres in the city.

\section{Participants}

The participants were all from the public secondary schools described above. While the study was aimed at adolescent students from grades 7 to 10 , not all these grades were represented in each country (see Table 1). The junior high school in Indonesia has only grades 7 to 9 , while the education system in Malaysia does not allow examination classes (i.e., grades 9 and 11) to be disrupted by research. In the case of Thailand, grade 7 did not take part because the students had come from different schools at grade 6 and information about them was not complete at the time of the study. In total there were 1038 participants made up of 325 Indonesians, 291 Malaysians and 422 Thais. There were 363 male and 675 female students. The predominant mother tongues were Bahasa Indonesia, Bahasa Malaysia and the Thai language. The details are summarized in Table 2. 
Table 2

Background of Participants ( $N=1038)$

\begin{tabular}{|c|c|c|c|c|c|}
\hline & & Indonesia & Malaysia & $\begin{array}{l}\text { Thai- } \\
\text { land }\end{array}$ & $\mathbf{N}$ \\
\hline \multirow[t]{4}{*}{ Grade (Age) } & 7 (13 yrs) & 127 & 123 & 0 & 250 \\
\hline & 8 (14 yrs) & 99 & 28 & 152 & 279 \\
\hline & $9(15 \mathrm{yrs})$ & 99 & 0 & 146 & 245 \\
\hline & 10 (16 yrs) & 0 & 140 & 124 & 264 \\
\hline \multirow[t]{2}{*}{ Gender } & Male & 143 & 79 & 141 & 363 \\
\hline & Female & 182 & 212 & 281 & 675 \\
\hline \multirow[t]{7}{*}{ Mother tongue } & Malay & 0 & 254 & 0 & 254 \\
\hline & Chinese & 0 & 24 & 0 & 24 \\
\hline & Tamil & 0 & 8 & 0 & 8 \\
\hline & Indonesian & 274 & 0 & 0 & 274 \\
\hline & Javanese & 49 & 0 & 0 & 49 \\
\hline & Thai & 0 & 0 & 422 & 422 \\
\hline & Others & 2 & 5 & 0 & 7 \\
\hline Total enrolment & & 325 & 291 & 422 & 1038 \\
\hline
\end{tabular}

\section{Instrument}

A self-report WTC questionnaire was used to measure the WTC level of the participants. It had a 5-point Likert scale consisting of $1=$ Almost never willing, $2=$ Sometimes willing, $3=$ Willing half of the time, $4=$ Usually willing and $5=$ Almost always willing, as used by MacIntyre et al. (2001) and Peng (2007). The questionnaire, adapted from Pattapong (2010), had 14 items for WTC inside the classroom and 12 items for WTC outside the classroom. The questionnaire was translated into the three major languages by a language expert in each country concerned. Internal reliability of the questionnaire was high, with Cronbach alpha values of $.926, .883$ and .877 for overall WTC, WTC in the classroom and WTC outside the classroom respectively. 


\section{Procedure}

The data collection began after the respective school administration gave access to the researchers to conduct the study. For Indonesia and Malaysia, four teacher trainees from a Malaysian university who were undergoing a local practicum in Malaysia followed by an international teaching practicum in Indonesia assisted in the data collection. The trainees collected data from the classes they taught or classes that were available during the data collection. For the Thai school, a schedule to enter the classes selected by the school administrator was given to the doctoral student, who was assisted by some teachers. Prior to answering the questionnaires, all students were informed that their input would be kept confidential and used for research purposes only. The questionnaires were completed within 30 minutes of class time.

\section{RESULTS AND DISCUSSION}

The results are presented and discussed in the order of the research questions (RQs).

\section{Research Question 1}

RQ1 looked at responses in each situation of communication for Almost Never Willing (ANW) and Almost Always Willing (AAW) to communicate in English. The data in percentages are displayed in Figure 2.

Percentages of responses for almost never willing to communicate were much higher than those for almost always willing, indicating an overall low WTC. The contrast can be seen for the last 12 situations in Figure 2, which occur outside the classroom. The top five situations in which students were almost always willing to communicate in English were:

1. Saying 'thank you' in English when a classmate lends them something.

2. Asking classmates in English about the meaning of a word.

3. Asking their teacher in English about the meaning of a word.

4. Apologizing in English to a stranger.

5. Saying 'thank you' in English to a stranger. 


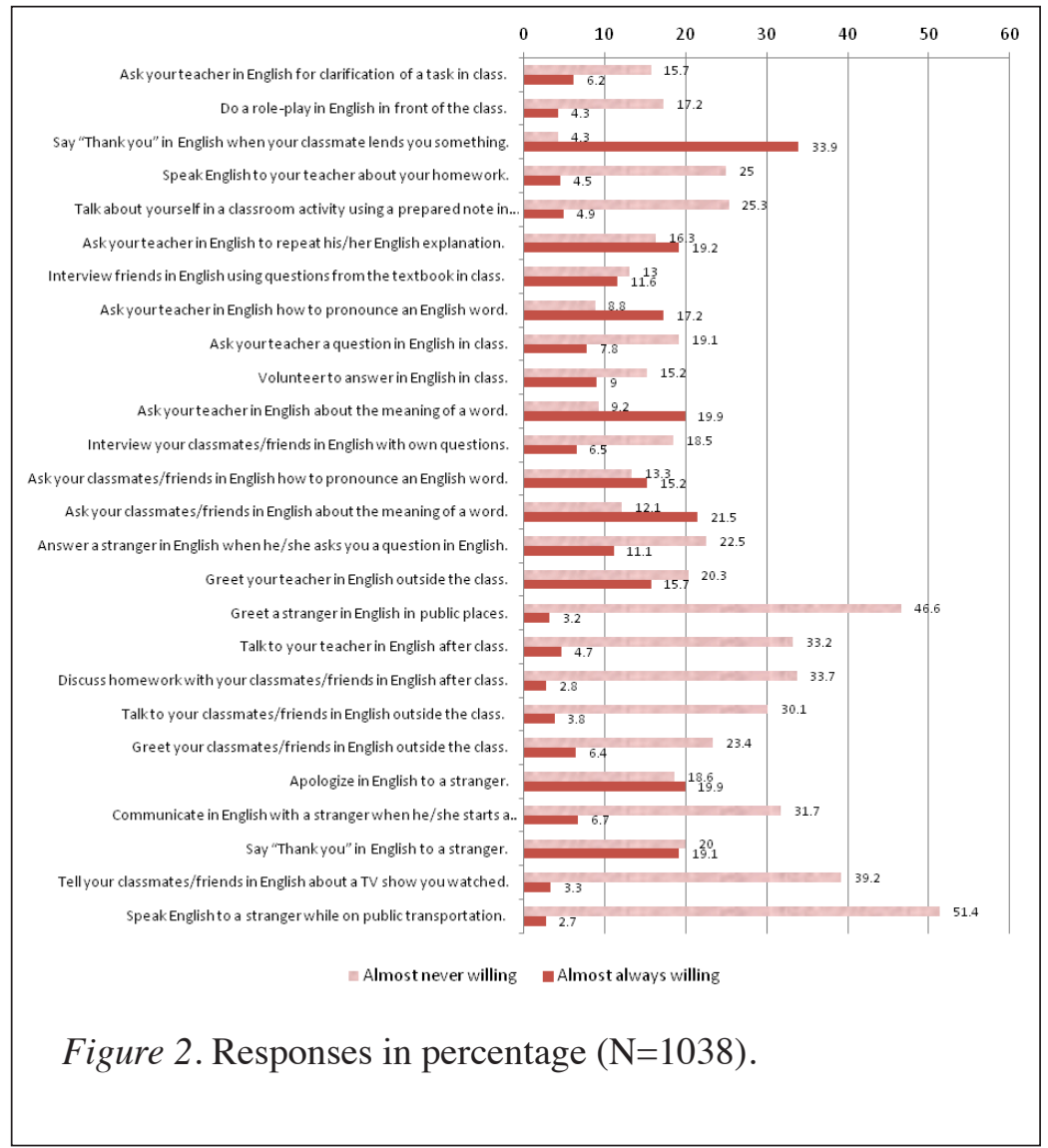

The first three situations above occur inside the classroom, while the last two occur outside. They are brief encounters which use set phrases like 'thank you' and 'sorry.' The learners were also quite willing to ask either their classmate or teacher for the meaning of a word. These situations can be considered non-threatening, where the attention is on the other person. The responsibility does not seem to be on the learner to talk at length.

The top five situations in which students were almost never willing to communicate in English are all found outside the classroom. They were:

1. Speaking English to a stranger on public transportation.

2. Greeting a stranger in English in public places.

3. Telling their friends in English about a TV show they watched. 
4. Discussing homework with classmates/friends in English after class.

5. Talking to their teacher in English after class.

In the Asian context where speaking to strangers is uncommon, it is not surprising that the high percentages of responses for unwillingness were found in situations involving strangers. Affiliation with a stranger is naturally low and the desire to communicate is further reduced when English is the tool of communication. In addition, the situations contain unpredictable and uncharted conversation paths that emerge to sustain a conversation. Even greeting a stranger in public might initiate an interaction that goes beyond set phrases, which the students likely did not possess.

Another highlight is that clear matches of high percentages for ANW with low percentages for AAW occurred in situations that have no fixed ways and language (set phrases, appropriate vocabulary) to maintain a conversation. The nature of such interactions might have caused the students to feel that they lacked the competence and confidence to perform. Students' low proficiency might be a factor, as reported in Tan and Phairot (2018) in the Thai school context. Similarly, Baghaei, Dourakhshan, and Salavati (2012) found that Iranian undergraduate students' WTC in the classroom and school setting showed the highest correlation with proficiency. Interestingly, they found that WTC with non-native speakers of English showed almost no correlation with proficiency in EFL, while WTC with native speakers showed the second highest correlation with proficiency. Thus, the interlocutors or conversation partners seemed to be important.

In the classroom, Thai students are less inclined to speak in English to their teacher for fear of making mistakes and losing face (Pattapong, 2010), an issue that is generally true among Asian students. We can relate the above findings with the analysis in Table 3 across two locations and three recipients.

The percentages indicating almost never willing to communicate in English with a teacher, a friend and a stranger outside the classroom were comparable, at $26.8 \%, 31.6 \%$ and $31.8 \%$ respectively, representing nearly a third of the 1038 respondents for each type of interlocutor. The closer affiliation that students had with their friends 
and teacher, in contrast with the lack of affiliation with strangers, did not seem to make them more willing to communicate in English with these more familiar interlocutors. It could be that the learners did not see one another as users of English and did not connect linguistically by using the L2 or FL. In non-native English speaking environments, opportunities to use English are generally rare. For example, lack of opportunity was a factor causing low WTC among first year students in an Indonesian university where either Javanese or Indonesian was used in daily interactions (Muamaroh \& Prihartanti, 2013).

Table 3

Mean Percentages of Responses by Location and Recipient $(N=1038)$

\begin{tabular}{lcc}
\hline Recipient and Location & ANW & AAW \\
\hline Teacher inside classroom & 15.7 & 12.5 \\
Teacher outside classroom & 26.8 & 10.2 \\
Friend inside classroom & 14.9 & 13.4 \\
Friend outside classroom & 31.6 & 4.1 \\
Stranger outside classroom & 31.8 & 10.5 \\
\hline
\end{tabular}

Note. ANW-almost never willing, AAW-almost always willing

Greater WTC with the teacher was found in the classroom $(\mathrm{AAW}=12.5 \%)$ compared to outside the classroom (AAW=10.2\%). The teachers in this study might have felt that their role was to encourage students to speak in English in class more than outside of class (Vongsila \& Reinders, 2016). Therefore, what was done in the classroom did not continue beyond the classroom.

\section{Research Question 2}

For RQ2, the means and standard deviations were calculated and inferential statistics using the ANOVA were computed. The significance level was set at 0.05 . Table 4 provides a summary of these statistics. 
Table 4

Means, Standard Deviations of WTC and F Statistics

\begin{tabular}{llcccc}
\hline \multicolumn{1}{c}{ WTC } & Country & $\mathbf{N}$ & $\begin{array}{c}\text { Mean } \\
(\mathbf{M})\end{array}$ & SD & F statistics \\
\hline Overall & Indonesia & 325 & 2.52 & .693 & \\
& Malaysia & 291 & 2.74 & .642 & $\begin{array}{l}\mathrm{F}(2,1035)=7.93, \\
\mathrm{p}<0.05\end{array}$ \\
& Thailand & 422 & 2.68 & .757 & \\
\hline $\begin{array}{l}\text { In the } \\
\text { classroom }\end{array}$ & Indonesia & 325 & 2.77 & .734 & \\
& Malaysia & 291 & 2.92 & .684 & $\mathrm{~F}(2,1035)=4.88$, \\
& Thailand $<0.05$ \\
\hline $\begin{array}{l}\text { Outside } \\
\text { the class- } \\
\text { room }\end{array}$ & 422 & 2.93 & .810 & \\
& Mndonesia & 325 & 2.23 & .785 & $\mathrm{~F}(2,1035)=11.04$, \\
& Malaysia & 291 & 2.53 & .715 & $\mathrm{p}<0.05$ \\
\hline
\end{tabular}

On a scale of 1 to 5, WTC mean levels for the locations of inside and outside the classroom ranged from 2.23 to 2.93 . This range is considered moderate, as in the findings in Tan and Phairot's (2018) study among Thai $12^{\text {th }}$ graders. The adolescents were generally "sometimes willing" and "willing half of the time" to communicate in English. As illustrated in Figure 3, Malaysians were generally the most willing and Indonesians the most unwilling speakers of English.

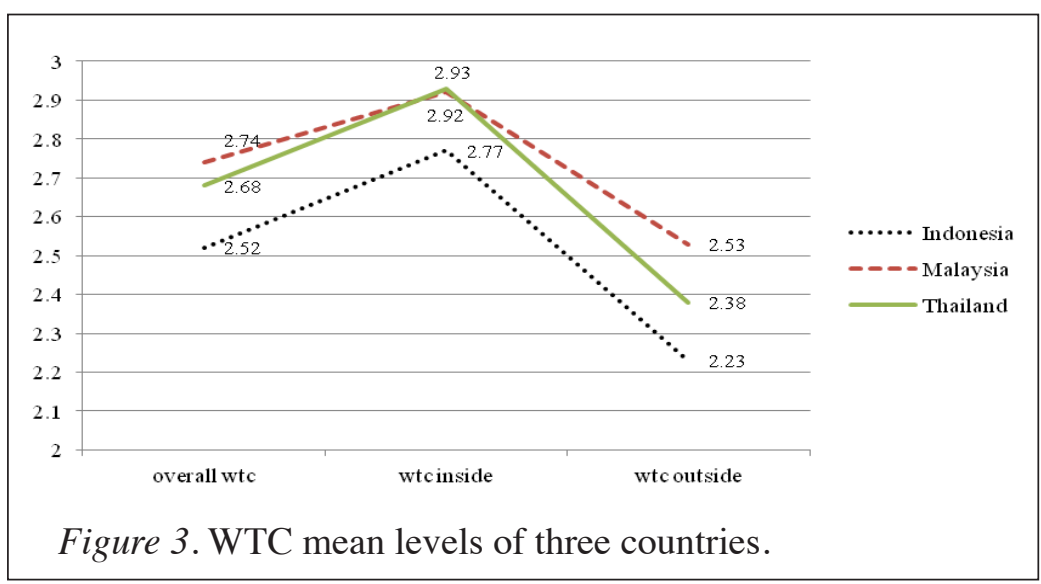


The F statistics showed there were statistically significant differences between groups in all three measurements. A post hoc Tukey analysis was subsequently performed. Overall WTC in Indonesia $(\mathrm{M}=2.52)$ was significantly lower than that in Malaysia $(\mathrm{M}=2.74$, $\mathrm{p}=.001)$ and Thailand $(\mathrm{M}=2.68, \mathrm{p}=.007)$. Similarly, WTC inside the classroom in Indonesia $(M=2.77)$ was significantly lower than that in Malaysia $(\mathrm{M}=2.92, \mathrm{p}=.04)$ and Thailand $(\mathrm{M}=2.93, \mathrm{p}=.01)$. There was no significant difference in overall WTC as well as WTC inside the classroom between Malaysia and Thailand $(\mathrm{p}=.529$ and $\mathrm{p}=.964$ respectively). However, WTC outside the classroom in Thailand $(\mathrm{M}=2.38)$ was significantly lower than that in Malaysia $(\mathrm{M}=2.53$, $\mathrm{p}=.042)$. WTC outside the classroom in Indonesia $(\mathrm{M}=2.23)$ was significantly lower than that in Malaysia $(\mathrm{M}=2.53, \mathrm{p}=.001)$ and Thailand $(\mathrm{M}=2.38, \mathrm{p}=.023)$.

It is not surprising to find greater WTC in Malaysia as compared to the two EFL countries. According to Lee (2015), the most popular variety of English used in non-formal situations in Malaysia is the "colloquial variety of the Malaysian English (CMalE)" which "presents an easier avenue for Malaysians to get their messages across, and is known among Malaysians as 'effective' English as it is short and simple, with influences of other languages to insert a local flavour, and closeness into the language" (p. 1). While English is hardly used among students in rural schools, urban dwellers in Kuala Lumpur and Penang, for example, have a high exposure to English and do use it (among other languages in their repertoire) in daily communication. With more people sharing this common language of interaction, the affiliation among interlocutors is strengthened, leading to greater WTC. In contrast, in Indonesia for example, the use of English is not as widespread although there is an increasing practice of mixing English vocabulary with the local languages in conversations (Renandya, 2000).

\section{Research Question 3}

To answer RQ3, the paired samples t test was used to identify significant differences between WTC inside and outside the classroom for each country. The results were $\mathrm{t}(290)=12.03, \mathrm{p}<0.01$ for Malaysia, $\mathrm{t}(324)=15.55, \mathrm{p}<0.01$ for Indonesia, and $\mathrm{t}(421)=19.38, \mathrm{p}<0.01$ for Thailand. This meant that there were significant differences in WTC between the two locations, where WTC inside was significantly 
higher than WTC outside the classroom. This was also found in Tan and Phairot's (2018) study. The results were also consistent with the findings of RQ1 in which a high percentage of participants indicated unwillingness to communicate in English in many situations outside the classroom (see Figure 2). Similarly, Peng's (2013) study found that Chinese undergraduates reporting willingness in the classroom outnumbered those indicating willingness outside, and higher mean scores were found for scale items that pertained to WTC inside the classroom. Peng suggested that a lack of real-life situations requiring the use of English, oral communication in the classroom as a coursework requirement and personal language achievement through using English in the classroom could explain the results.

\section{CONCLUSION}

WTC is one of the prerequisites for learning or acquisition of English as either a second or foreign language. Higher WTC will open up more opportunities for using English and ultimately lead to better mastery of the language. Viewed as a dynamic state, willingness is situational and unwillingness is "treatable." In this respect, while the situated antecedents in Layer III of MacIntyre et al.'s (1998) heuristic model help to explain the empirical data on WTC inside and outside the classroom, it points to the need for finding the treatment. Understanding in greater depth the learning context as well as the diverse contexts in which communication takes place brings one closer to the solution in enhancing willingness. The ESL/EFL learning context in Southeast Asia is marked by a teacher who is usually a non-native speaker of English and an authoritative figure. Additionally, the outside environment is not really populated by speakers of English. In light of the results of the present study, English teachers as interlocutors and classroom instructors may hold the key to their students' WTC.

\section{Implications for Practice}

Some implications for practice can be drawn from the findings of this study, from the perspective of situated antecedents within the non-native English speaking context of Southeast Asia. As WTC is higher in the classroom, the place to start nurturing willingness to interact in English is logically the classroom. In this regard, the 
role of the teacher is important as an implementer of pedagogical interventions which include the selection of conversation topics, increasing the students' repertoire of set phrases and use of strategies that increase opportunities to communicate in English. Appropriate pedagogy with regard to WTC is necessary for preparing students for authentic communication with speakers of English outside the classroom.

One way to increase WTC is by creating and strengthening affiliations among interlocutors in the classroom through the use of English. If more English is used among teachers and students in the classroom, this practice hopefully will spill over to situations outside the classroom. Teachers and students should consider each other as users of English wherever they may be and not feel uneasy communicating in English outside the formal teaching environment. To take the lead, English teachers should themselves model willingness and be seen to use English more frequently whether inside or outside the classroom. This would mean exhibiting the uniqueness of "being" an English teacher (Gee, 1996; Tan \& Miller, 2007) in the ESL/EFL context.

\section{LIMITATIONS OF THE STUDY}

It is not the intention of the authors to generalise the findings of this study to the countries represented or to the larger non-native English speaking population. Every ESL or EFL context of learning and use of English is unique. Even within the same country, English is viewed differently in different geographic locations as well as sectors of society. For example, students from town schools and wealthy backgrounds normally have a greater exposure to English and this might affect their WTC. This study only had the chance to survey four schools in specific locations. Even if more schools were covered, at best a profile of the willing speaker of English might have emerged.

Another point that should be noted is the inadequacy of items in the questionnaire to capture WTC outside the classroom (Peng, 2013). Items that involve a stranger as the interlocutor might be problematic. Students in the Asian culture may not be willing to communicate with a stranger, whether in English or their mother tongue. Thus items on 
WTC outside the classroom should be more carefully formulated to use situations that are "contextually expected" (p. 288).

\section{FUTURE RESEARCH}

This was a quantitative study that used a self-report questionnaire to measure the students' WTC levels. It can be considered a baseline study to suggest areas worth pursuing in future studies. An interesting area would be whether the almost never willing (ANW) and almost always willing (AAW) communication situations would differ for learners of different ages and gender. As reviewed by Dixon and Wu (2014), gender has been found to affect interaction behaviours of Iranian, Japanese and Taiwanese EFL learners. How is WTC affected when the interlocutors are from the opposite gender?

A qualitative component to the research approach would definitely have yielded stronger support for the trends reported here. Qualitative approaches can be used to elicit from students and teachers what they consider as factors that affect WTC. Qualitative data will be able to provide richer descriptions of culture-specific and classroomspecific WTC, as well as the interplay of influences.

Studies on the effectiveness of certain instructional interventions in enhancing WTC among different groups of ESL/EFL learners are recommended. For example, communication strategies (Maleki, 2007), digital games (Reinders \& Wattana, 2011), oral presentations of books read (Matsuoka et al., 2014), opportunities to talk (Allahyar, 2014) and questioning techniques (Nazari \& Allahyar, 2012) are possible treatments in experimental studies on WTC. Another area of research can examine whether actual or perceived communicative competence is a better predictor of WTC. Since the English proficiency of the ESL/EFL learners is generally low, willingness to speak in situations requiring only set phrases as found in the present study, may be due to actual rather than perceived communicative competence, contrary to the findings of MacIntyre and Charos (1996).

Lastly, to recognise and exploit the online literacy practices and online communication of the students, it is necessary to conduct studies on the affordances of the Internet and "membership of 
a global community" (Peng, 2013, p. 288) as factors of WTC. Contemporary online practices might compensate for the lack of opportunities for authentic communication in English in the ESL/ EFL learners' everyday experiences outside the physical classroom.

\section{ACKNOWLEDGEMENTS}

This research received no specific grant from any funding agency.

\section{REFERENCES}

Allahyar, N. (2014). Iranian EFL students' willingness to communicate or reticence: Teacher perceptions, interaction patterns and strategies (Unpublished doctoral thesis). Universiti Sains Malaysia, Malaysia.

Alwasilah, A. C. (2013). Policy on foreign language education in Indonesia. International Journal of Education, 7(1), 1-19.

Baghaei,P., Dourakhshan,A.,\& Salavati, O. (2012). The relationship between willingness to communicate and success in learning English as a foreign language. Modern Journal of Applied Linguistics, 4(2), 53-67.

Baker, S. C., \& MacIntyre, P. D. (2000). The role of gender and immersion in communication and second language orientations. Language Learning, 50(2), 311-341. doi:10.1111/00238333.00119

Cameron, D. (2013). Willingness to communicate in English as a second language as a stable trait or context-influenced variable: Case studies of Iranian migrants to New Zealand. Australian Review of Applied Linguistics, 36(2), 177-196. doi:10.1075/aral.36.2.04cam

Cameron, D. (2015). 'In New Zealand I feel more confidence': The role of context in the willingness to communicate (WTC) of migrant Iranian English language learners. International Journal of English Studies, 15(2), 61-80. doi:10.6018/ ijes/2015/2/202981

Cao, Y. (2011). Investigating situational willingness to communicate within second language classrooms from an ecological perspective. System, 39(4), 468-479. doi:10.1016/j. system.2011.10.016 
Cao, Y., \& Philp, J. (2006). Interactional context and willingness to communicate: A comparison of behaviour in whole class, group and dyadic interaction. System, 34, 480-493. doi:10.1016/j.system.2006.05.002

Compton, L. K. (2002). From chatting to confidence: A case study of theimpact of online chatting oninternational teaching assistants' willingness to communicate, confidence level and fluency in oral communication. Retrospective Theses and Dissertations. Paper 14445. Retrieved from http://lib.dr.iastate.edu/cgi/ viewcontent.cgi?article $=15444 \&$ context $=$ rtd

Dixon, L. Q., \& Wu, S. (2014). Understanding language learning: Review of the application of the interaction model in foreign language contexts. Malaysian Journal of Learning and Instruction, 11, 23-39.

Gee, J. P. (1996). Social linguistics and literacies (2nd ed.). London: Taylor \& Francis.

Kang, S.-J. (2005). Dynamic emergence of situational willingness to communicate in a second language. System, 33, 277-292. doi:10.1016/j.system.2004.10.004

Lahuerta,A.C. (2014). Factors affecting willingness to communicate in a Spanish university context. International Journal of English Studies, 14(2), 39-55. doi:10.6018/j.193611

Lauder, A. (2008). The status and function of English in Indonesia: A review of key factors. Makara, Sosial Humaniora, 12(1), 9-20.

Lee, Z. E. (2015). Colloquial Malaysian English (CMalE): A problem or a cool phenomenon? (Unpublished master's thesis). Universitat Jaume I, Spain. Retrieved from http:// repositori.uji.es/xmlui/bitstream/handle/10234/127527/ TFM_Lee_Zhia_Ee.pdf?sequence $=1$

Maleki, A. (2007). Teachability of communication strategies: An Iranian experience. System, 35, 583-594. doi: 10.1016/j. system.2007.04.001

MacIntyre, P. D. (1994). Variables underlying willingness to communicate: A causal analysis. Communication Research Reports, 11, 135-142.

MacIntyre, P. D., Babin, P. A., \& Clément, R. (1999). Willingness to communicate: Antecedents \& consequences. Communication Quarterly, 47(2), 215-229. doi:10.1080/01463379909370135

MacIntyre, P. D., \& Charos, C. (1996). Personality, attitudes, and affects as predictors of second language communication. Journal of Language and Social Psychology, 15(1), 3-26. doi:10.1177/0261927X960151001 
MacIntyre, P. D., Baker, S. C., Clément, R., \& Conrod, S. (2001). Willingness to communicate, social support, and languagelearning orientations of immersion students. Studies on Second Language Acquisition, 23, 369-388. doi:10.1017/ S0272263101003035

MacIntyre, P. D., Clément, R., Dörnyei, Z., \& Noels, K. (1998). Conceptualizing willingness to communicate in a L2: A situational model of L2 confidence and affiliation. The Modern Language Journal, 82(4), 545-562.

Matsuoka, R. (2004). Willingness to communicate in English among Japanese college students. Proceedings of the $9^{\text {th }}$ Conference of Pan-Pacific Association of Applied Linguistics (pp. 165176). Cheonan, Korea: Namseoul University. Retrieved from http://www.paaljapan.org/resources/proceedings/PAAL9/pdf/ Matsuoka.pdf

Matsuoka, R., Matsumoto, K., Poole, G., \& Matsuoka, M. (2014). Japanese university students' willingness to communicate in English: The serendipitous effect of oral presentations. Journal of Pan-Pacific Association of Applied Linguistics, 18(1), 193-218.

McCroskey, J. C., \& Baer, J. E. (1985, November). Willingness to communicate: The construct and its measurement. Paper presented at the Annual Meeting of the Speech Communication Association, Colorado, U.S.A.

Ministry of Education of Malaysia. (2013). Malaysia education blueprint 2013-2025. Retrieved from http://www.moe.gov. my/images/dasar-kpm/articlefile_file_003108.pdf

Ministry of Education Thailand. (2008). Basic education core curriculum B.E. 2551 (A.D. 2008). Bangkok: Ministry of Education Thailand.

Muamaroh., \& Prihartanti, N. (2013). Willingness to communicate in English: A case study of Indonesian university students. Kajian Linguistik dan Sastra, 25(1), 71-81.

Nazari, A., \& Allahyar, N. (2012). Increasing willingness to communicate among English as a Foreign Language (EFL) students: Effective teaching strategies. Investigations in University Teaching and Learning, 8, 18-29.

Pattapong, K. (2010). Willingness to communicate in a Second Language: A qualitative study of issues affecting Thai EFL learners from students' and teachers' point of view (Unpublished doctoral thesis). Faculty of Education and Social Work, University of Sydney, Australia. 
Peng, J. (2007). Willingness to communicate in an L2 and integrative motivation among college students in an intensive English Language program in China. University of Sydney Papers in TESOL, 2, 33-59.

Peng, J. (2012). Towards an ecological understanding of willingness to communicate in EFL classrooms in China. System, 40(2), 203-213. doi:10.1016/j.system.2012.02.002

Peng, J. (2013). The challenge of measuring willingness to communicate in EFL contexts. Asia-Pacific Education Researcher, 22(3), 281-290. doi:10.1007/s40299-012-0053-x

Piechurska-Kuciel, E. (2014, April). Proximal predictors of L2 willingness to communicate in Polish adolescents. In $\mathrm{N}$. Lavidas, T. Alexiou, \& A. M. Sougari (Eds.), Major Trends in Theoretical and Applied Linguistics. The 20 International Symposium on Theoretical and Applied Linguistics (Vol. 3, pp. 315-328). Thessaloniki, Greece: Aristotle University of Thessaloniki. Retrieved from https://www.degruyter. com/downloadpdf/books/9788376560915/9788376560915. p19/9788376560915.p19.pdf

Reinders, H., \& Wattana, S. (2011). Learn English or die: The effects of digital games on interaction and willingness to communicate in a foreign language. Digital Culture \& Education, 3(1), 3-29.

Renandya, W. A. (2000). Indonesia. In W. K. Ho \& R. Y. L. Wong (Eds.), Language policies and language education: The impact in East Asian countries in the next decade (pp.113137). Singapore: Times Academic Press.

Tan, K. E., \& Miller, J. (2007). Writing in English in Malaysian high schools: The discourse of examinations. Language and Education, 21(2), 124-140. doi:10.2167/le663.0

Tan, K. E., \& Phairot, E. (2018). Willingness to communicate among Thai EFL students: Does English proficiency matter? Journal of Asia TEFL, 15(3), 590-602. doi:10.18823/ asiatefl.2018.15.3.2.590

The Educational Management Information System: EMIS. (2017). Thai government school profile. Retrieved from http:// data.bopp-obec.info/emis/schooldata view.php?School_ $\mathrm{ID}=1092140338 \&$ Area_CODE $=101713$

Vongsila, V., \& Reinders, H. (2016). Making Asian learners talk: Encouraging willingness to communicate. RELC Journal, 47(3), 331-347. doi:10.1177/0033688216645641 
Wen, W. P., \& Clément, R. (2003). A Chinese conceptualization of willingness to communicate in ESL. Language, Culture and Curriculum, 16, 18-38. doi:10.1080/07908310308666654

Yashima, T. (2002). Willingness to communicate in a second language: The Japanese EFL context. The Modern Language Journal, 86, 54-66. doi:10.1111/1540-4781.00136

Yashima, T.,Zenuk-Nishide, L., \& Shimizu, K. (2004). The influence of attitudes and affect on willingness to communicate and second language communication. Language Learning, 54, 119-152. doi:10.1002/tesq. 155

Zhong, Q. (2013). Understanding Chinese learners' willingness to communicate in a New Zealand ESL classroom: A multiple case study drawing on the theory of planned behaviour. System, 41(3), 740-751. doi:10.1016/j.system.2013.08.001 